\title{
PEMANFAATAN SAMPAH ORGANIK DAN LIMBAH KOTORAN HEWAN SEBAGAI ENERGI BARU TERBARUKAN RAMAH LINGKUNGAN
}

\author{
Lutfi Wicaksono $^{1 *}$, Denny Dermawan', Gigih Alam Pambudi, Moch Luqman Ashari', Adhi Setiawan', \\ Novi Eka Mayangsari ${ }^{1}$, Ahmad Erlan Afiuddin ${ }^{1}$, Mochammad Choirul Rizal ${ }^{1}$, Tanti Utami Dewi ${ }^{1}$, Ulvi Pri \\ Astuti $^{1}$, Alma Vita Sophia ${ }^{1}$, Bella Naziel Iqmalia ${ }^{2}$, Fani Firmansyah', Rafi Narariya Ramadhan ${ }^{1}$, Imam \\ Hambali Azhori ${ }^{1}$, Bagas Adhiwangsa ${ }^{1}$ \\ ${ }^{1}$ Waste Treatment Engineering, PPNS \\ ${ }^{2}$ Occupational Safety and Health Engineering, PPNS \\ Surabaya \\ e-mail: lutfiwicaksonok3@gmail.com
}

diterima tanggal : 2 September 2018 disetujui tanggal : 20 November 2018

\begin{abstract}
Abstrak
Masalah akibat kepadatan penduduk adalah meningkatnya sampah yang mencakup keseluruhan wilayah, baik perkotaan maupun pedesaan. Sampah di wilayah pedesaan didominasi oleh sampah organik pasar dan limbah peternakan. Tidak berjalannya sistem pengolahan dan pendistribusian sampah yang baik, menyebabkan penumpukan sampah seperti pada wilayah Dusun Gedangklutuk, Desa Kedungboto, Kabupaten Pasuruan. Kegiatan ini bertujuan untuk memanfaatkan sampah organik dan limbah peternakan sebagai Energi Baru Terbarukan (EBT) ramah lingkungan dengan metode biodigester. Biodigester mampu mengubah sampah organik pasar menjadi biogas yang memiliki kandungan CH4 sekitar 50-75\%, CO2 sekitar 25-50\%, dan sisanya adalah gas lain yang persentasenya sangat kecil. Gas berasal dari penguraian bahan organik oleh bakteri anaerob dengan suhu optimum sekitar $30-35^{\circ} \mathrm{C}$ dan $\mathrm{pH}$ sekitar 6-8. Biodigester menghasilkan 847,8 liter gas yang tertampung.
\end{abstract}

Keyword: sampah organik, limbah peternakan, biodigester, energy baru terbarukan

\begin{abstract}
The problem due to population density is about increasing solid waste in all regions, both urban and rural areas. The solid waste that dominates in rural areas are market organic wastes and farm garbage. The ineffectiveness of the solid waste treatment and distribution system can cause solid waste accumulation, such as in the Gedangklutuk Hamlet, Kedungboto Village, Pasuruan Regency. This activity aims to utilize organic and farm garbage as environmentally friendly New Renewable Energy (NRE) using a biodigester method. This biodigester converts organic waste into biogas which has CH4 content approximately 50-75\%, CO2 around $25-50 \%$, and small percentage of remains gasses. The gas source from a decomposition of materials by anaerobic bacteria with an optimum temperature around 30-35 ${ }^{\circ} \mathrm{C}$ and $\mathrm{pH}$ level around 6-8. The result of biodigester are 847.8 liters of gas stored.
\end{abstract}

Keyword: organic waste, farm garbage, biodigester, new renewable energy

\section{PENDAHULUAN}

Cadangan energi di Indonesia yang semakin menipis membuat masyarakat Indonesia semakin dekat dengan krisis energi. Saat ini Indonesia menjadi negara dengan konsumsi energi yang cukup tinggi di dunia. Berdasarkan data dari
Direktorat Jendral Energi Baru Terbarukan dan Konservasi Energi Kementrian ESDM, dalam beberapa tahun terakhir pertumbuhan konsumsi energi Indonesia mencapai 7\% per tahun. Angka tersebut berada di atas pertumbuhan konsumsi energi dunia yaitu sebesar $2,6 \%$ per tahun. Berdasarkan Renstra Direktorat Minyak dan Gas 
Bumi untuk tahun 2015-2019 Kementrian ESDM, Industri minyak nasional Indonesia sudah berumur cukup tua sekitar 100 tahun menyebabkan semakin tahun produksi minyak Indonesia semakin menurun. Sepanjang sejarah produksi minyak, puncak produksi hanya terjadi sebanyak 2 (dua) kali yaitu pada tahun 1977 dan 1995 dengan produksi minyak sebesar 1,68 juta bpd dan 1,62 bpd, setelah itu produksi minyak Indonesia tidak pernah mencapai angka-angka tersebut, padahal masyarakat Indonesia adalah konsumen terbesar bahan bakar fosil (fossilfuels).

Disisi lain masalah lama yang semakin kompleks di Indonesia adalah timbulan sampah. Menurut Kementerian Lingkungan Hidup dan Kehutanan, peningkatan jumlah penduduk di Indonesia berbanding lurus dengan jumlah sampah yang tiap hari dihasilkan. Hitungan secara kasar, dengan jumlah penduduk Indonesia saat ini yang lebih dari 250 juta orang, jika setiap orang menghasilkan sampah $0,7 \mathrm{~kg} /$ hari, maka timbunan sampah secara nasional mencapai 175 ribu ton/ hari atau setara dengan 64 juta ton/tahun. Adapun presentase sampah organic seperti sisa makanan, buah-buahan, dan sayur-sayuran mencapai $65,05 \%$ [1]. Sering tidak disadari bahwa sampah-sampah organik jumlahnya banyak dan jarang tersentuh pemanfaatan yang efektif. Salah satu penyumbang terbanyak sampah organic adalah pasar tradisional.

Problem sampah mencakup keseluruhan wilayah baik pedesaan maupun perkotaan. Sampah di wilayah pedesaan didominasi oleh sampah organik pasar. Rata- rata satu pasar tradisional akan menghasilkan 5-8 ton sampah perhari yang $70 \%$ didominasi sampah organik. Dua masalah besar terkait energi dan sampah sangat terasa di Desa Kedungboto, Kecamatan Beji, Kabupaten Pasuruan. Terlihat jelas seperti TPS yang berada di Dusun Gedang Klutuk, sampah yang didominasi dengan sampah organic menumpuk dan masih belum ada pendistribusian sampah ke TPABaujeng, begitu halnya sampah yang terkumpul tiap harinya diPasar Ikan Asap yang tidak dilakukan pemilahan sampah.

Sampah di Desa Kedungboto, sistem pembuangan sampah terhenti hanya sampai di TPS saja. Sampah yang didominasi dari sampah organik sangat berpotensi menjadi sumber bau busuk dan penyakit untuk masyarakat sekitar, terlebih lagi TPS dadakan ini bertempat di sebelah utara Pusat Ikan Asap yang menjadi sentra pusat oleh-oleh desa, hingga tak jarang konsumen merasa risih dengan adanya pemandangan tersebut. Kondisi lokasi TPS dan suasana desa Desa Kedungboto dapat dilihat pada Gambar 1.1

Menghadapi dua masalah kompleks yaitu tentang energi dan sampah dapat memunculkan korelasi antar satu dengan yang lain, indikator kemajuan ekonomi suatu negara terukur dari keberadaan energi yang mendukung dan minimnya limbah yang dihasilkan. Untuk itu, perlu adanya pemanfaatan sampah menjadi energi sebagai pengganti energy yang tak dapat diperbaharui. Energi biogas adalah salah satu dari banyak macam sumber energi terbarukan, karena energi biogas dapat diperoleh dari sampah pasar. Energi biogas dihasilkan dari proses fermentasi bahan-bahan organic dengan bantuan bakteri anaerob pada lingkungan tanpa oksigen bebas. Energi biogas didominasi oleh gas metana (50\%$75 \%), \mathrm{CO} 2(25 \%-50 \%), \mathrm{N} 2(0-10 \%), \mathrm{H} 2(0-1 \%)$ dan $\mathrm{O} 2(0-2 \%)$. Pada dasarnya pembuatan biogas sangat sederhana, melaui pencampuran sampah organik dengan bakteri anaerob. Dalam waktu tertentu biogas akan terbentuk, selanjutnya akan dijadikan energy alternative sebagai bahan bakar alternative ramah lingkungan (environmental friendly).

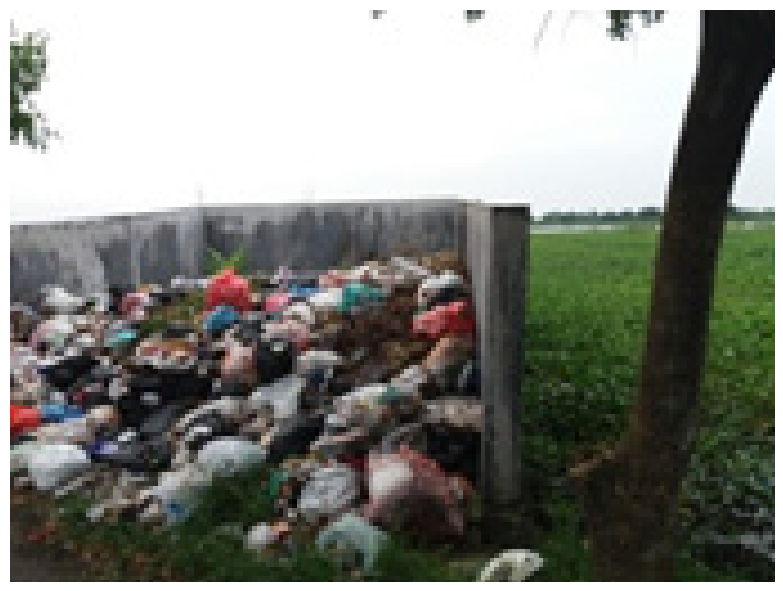

Gambar 1.1 TPS Desa Kedungboto Sumber : Hasil Survey,2018 


\section{TINJAUAN PUSTAKA}

A. Pembentukan Biogas

Biogas secara karakteristik fisik merupakan gas. Karena itu, proses pembentukannya membutuhkan ruangan dalam kondisi kedap atau tertutup agar stabil. Pada prinsipnya, biogas terbentuk melalui beberapa proses yang berlangsung dalam ruang yang anaerob atau tanpa oksigen. Mekanisme pembentukan biogas secara umum [2]:

\section{Mikroorganisme anaerob}

Bahanorganik $\longrightarrow \mathrm{CH} 4+\mathrm{CO} 2+\mathrm{H}_{2}+\mathrm{NH} 3 . .(1)$

Pembentukan biogas secara keseluruhan terdapat tiga proses utama dalam pembentukan biogas, yaitu proses hidrolisis, pengasaman, dan metanogenesis. Keseluruhan proses ini tidak terlepas dari bantuan kinerja mikroorganisme anaerob.

\section{a. Hidrolisis}

Hidrolisis merupakan tahap awal dari proses fermentasi. Tahap ini merupakan penguraian bahan organik dengan senyawa kompleks yang memiliki sifat mudah larut seperti lemak, protein, dan karbohidrat menjadi senyawa yang lebih sederhana. Senyawa yang dihasilkan dari proses ini diantaranya asam organik, glukosa, etanol, $\mathrm{CO} 2$, dan senyawa hidrokarbon lainnya. Senyawa ini akan dimanfaatkan mikroorganisme sebagai sumber energi untuk melakukan aktivitas fermentasi [2].

\section{(C6H10O5) $n+n H 2 O \longrightarrow n(C 6 H 12 O 6) . .(2)$}

Beberapa faktor yang dapat mempengaruhi derajat dan laju hidrolisis substrat, di antaranya adalah :

- Suhu operasionaldigester

- Waktu tinggal substrat di dalam digester

- Komposisi substrat (yaitu kandungan lignin, karbohidrat, protein, dan lemak)

- Ukuranpartikel

- $\mathrm{pH}$ medium

- Konsentrasi NH4+-N

- Konsentrasi produk hisrolisis(VFA)

Produk yang dapat larut pada fase hidrolisis ini dimetabolisasi di dalam sel-sel bakteri fermentatif dan dikonversi menjadi beberapa senyawa yang lebih sederhana, yang kemudian dibuang oleh sel. Senyawa yang dihasilkan meliputi VFA, alkohol, asam laktat, $\mathrm{CO} 2, \mathrm{H} 2$, ammonia, H2S, dan sel-sel baru bakteri [3].

\section{b. Pengasaman (Asidifikasi)}

Senyawa-senyawa yang terbentuk pada tahap hidrolisis akan dijadikan sumber energi bagi mikroorganisme untuk tahap selanjutnya, yaitu Pengasaman atau asidifikasi. Pada tahap ini, bakteri akan menghasilkan senyawa-senyawa asam organik seperti asam asetat, asam propionat, asam butirat, dan asam laktat beserta produk sampingan berupa alkohol, CO2, hidrogen, dan zat amonia [4].

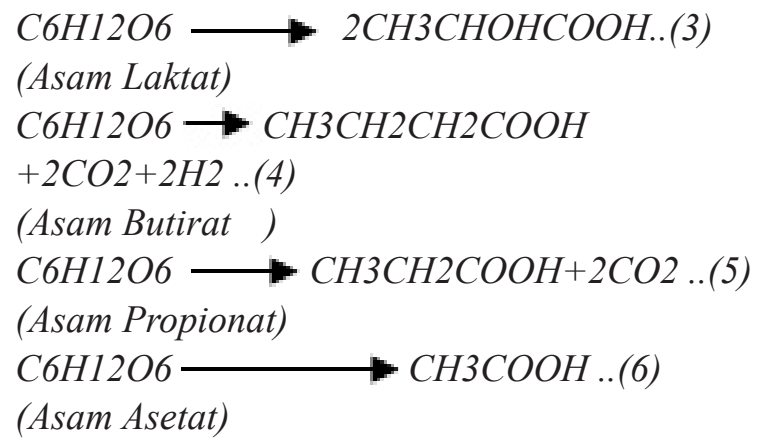

Produksi dari fase asidogenik berfungsi sebagai substrat untuk bakteri lain, dari fase asedogenik. fase acetogenic membatasi laju degradasi dalam tahap akhir. dari kuantitas suatu komposisi biogas, kesimpulan dapat ditarik tentang aktivitas bakteri asetogenik. Pada waktu yang sama, senyawa nitrogen organik dan sulfur dapat termineralisasi ke hidrogen sulfur dengan memproduksi amonia [4].

$$
\begin{aligned}
& \mathrm{SO} 42-+\mathrm{CH} 3 \mathrm{COOH} \rightarrow \mathrm{HS}_{-}+\mathrm{CO}_{2}+\mathrm{HCO}_{-}- \\
& +\mathrm{H} 2 \mathrm{O} \ldots \ldots . .(7) \\
& \mathrm{SO} 42-+2 \mathrm{CH} 3 \mathrm{CHOHCOOH} \rightarrow \mathrm{HS}-+2 \mathrm{CH} 3 \mathrm{COOH} \\
& +\mathrm{CO} 2+\mathrm{HCO}_{-}- \\
& +\mathrm{H} 2 \mathrm{O} \ldots \text {...(8) }
\end{aligned}
$$

\section{c. Metanogenesis}

Bakteri metanogen seperti methanococus, methanosarcina, dan methano bactherium akan mengubah menjadi gas metan, karbondioksida,dan air yang merupakan komponen penyusun biogas. Berikut reaksi perombakan yang dapat terjadi pada tahap metanogenesis [2].

$4 \mathrm{H} 3+\mathrm{CO} 2 \longrightarrow \mathrm{HCOOH} \longrightarrow \mathrm{CH} 4+2 \mathrm{H} 2 \mathrm{O} . .(9)$
$4 \mathrm{CH} 4+\mathrm{CO} 2+2 \mathrm{H} 2 \mathrm{O} . .(10)$ 


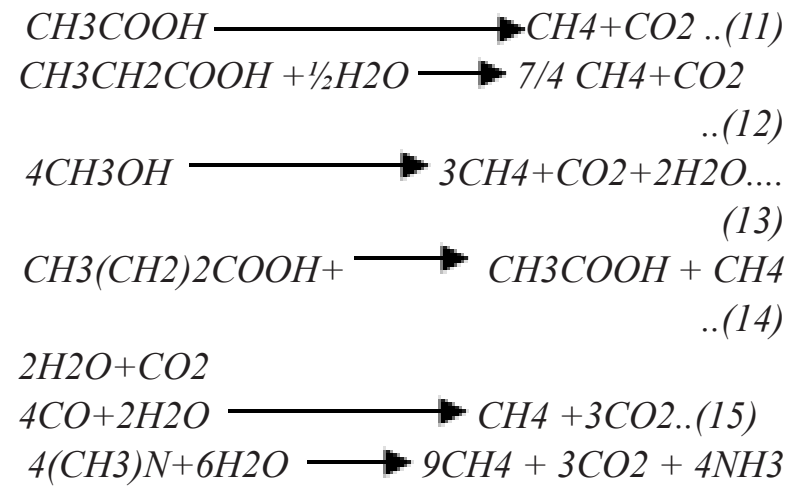

Jumlah energi yang dihasilkan dalam pembentukan biogas sangat bergantung pada konsentrasi gas metana yang dihasilkan pada proses metanogenesis.

Semakin tinggi kandungan metana yang dihasilkan, maka semakin besar pula energi yang terbentuk. Sebaliknya, apabila konsentrasi gas metana yang dihasilkan rendah, maka energi yang dihasilkan juga semakin rendah. Kualitas biogas yang dihasilkan juga dapat ditingkatkan melalui penghilangan hidrogen sulfur, kandungan air, dan karbondioksida yang turut terbentuk [5].

\section{METODOLOGI PELAKSANAAN}

A. Strategi

Strategi yang akan dilakukan oleh tim pengabdian adalah sebagai berikut:

1. Perancangan reaktor biogas.

2. Pemberian edukasi kepada masyarakat di Desa Kedungboto mengenai program pemanfaatan dan pemilahansampah.

3. Pemberian pelatihan pembuatan reaktor biogas.

4. Pembentukan mitra dan pelaku program pelatihan dan pendampingan teknis pembuatan reaktor biogas pengolah campuran sampah pasar dan limbah kandang ternak sebagai EBT (Energi Baru Terbarukan) RamahLingkungan.

5. Pemanfaatan hasilprogam.

6. Pendampingan teknis secara berkala.

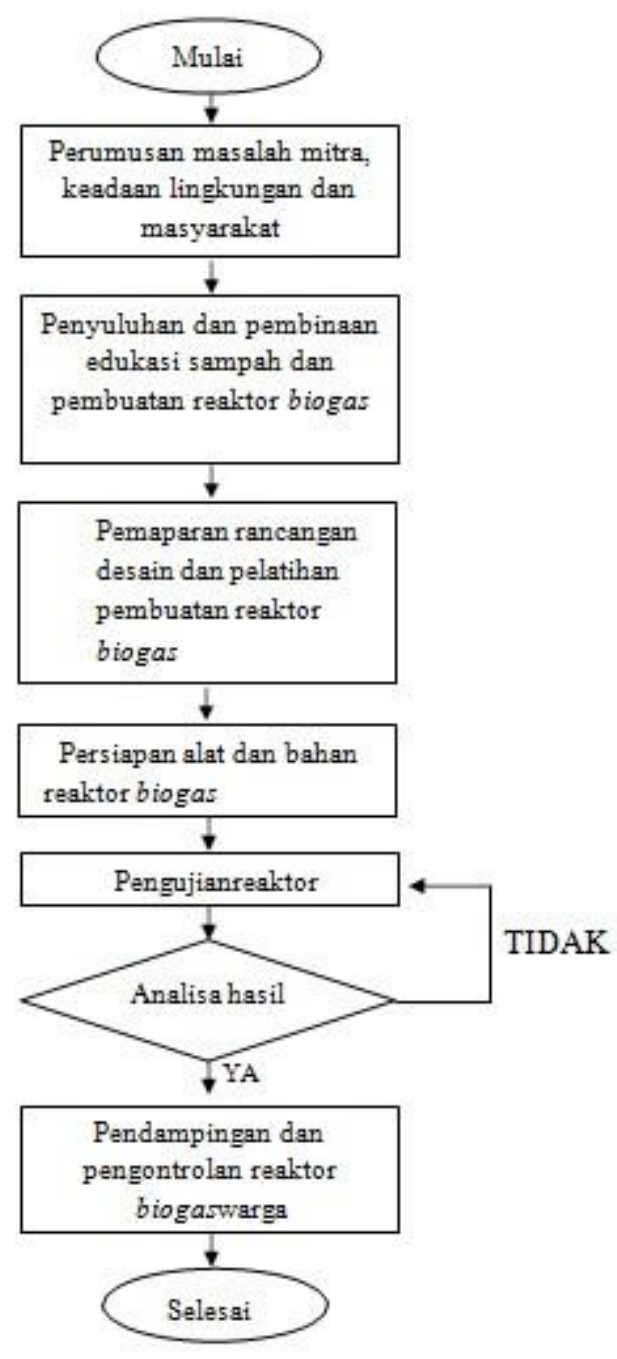

Gambar 2. Kerangka Konsep

\section{B. Rencana Kegiatan}

Untuk dapat mencapai target yang diharapkan dan menjalankan strategi yang telah direncanakan, maka kegiatan ini dilakukan dengan menggunakan tahapan kegiatan, diantaranya:

\section{a.Tahap Perancangan Reaktor}

Pada dasarnya sistem reaktor biogas portable terbagi menjadi 3 (tiga) bagian utama yaitu tangki biodigester, alat purifikasi, dan kerangka dudukan beroda. Rancangan reaktor biogas portable seperti Gambar 3.2 di bawah ini.

Rancangan dari alat purifikasi dapat dilihat pada Gambar 4. 


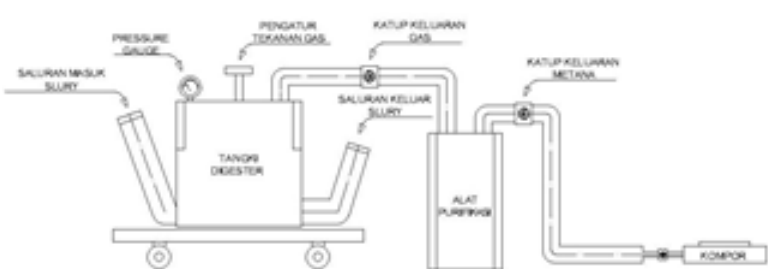

Gambar 3. Rancangan Reaktor Biogas Portable Sumber : Hasil Rancangan, 2018

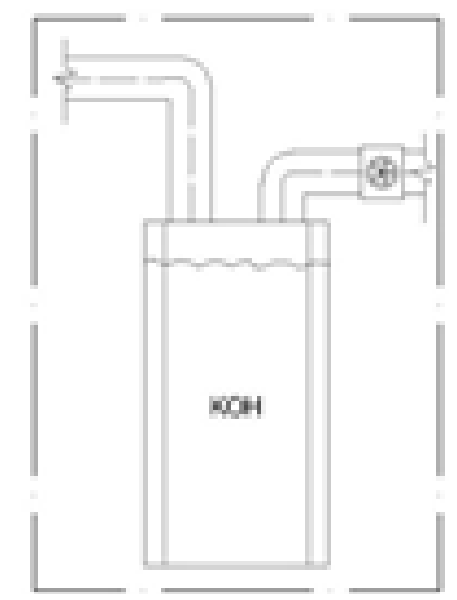

Gambar 4. Rancangan Alat Purifikasi Sumber : Hasil Rancangan, 2018

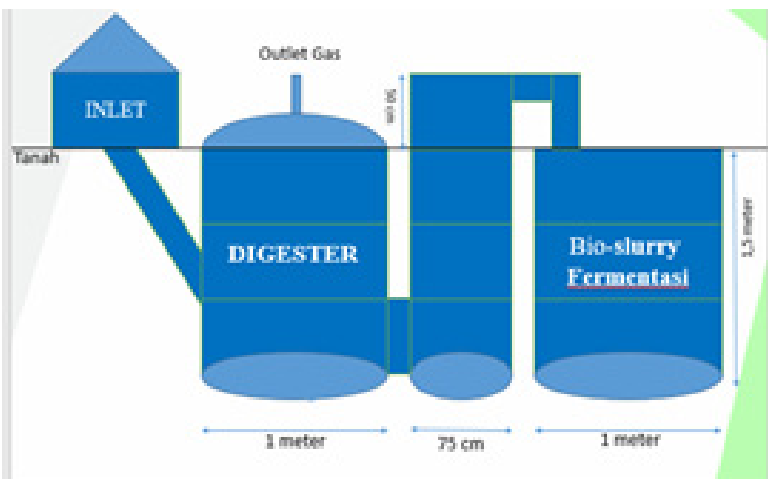

Gambar 5. Rancangan Biogas yang Diterapkan Sumber : Hasil Rancangan, 2018

Alat purifikasi terbuat dari kaca dan cairan di dalamnya adalah kalium hidroksida. Kalium hidroksida mampu mengikat $\mathrm{CO} 2$, sehingga diharapkan mampu menaikkan kualitas biogas yang murni mengandung metana. Di sisi lain, pengikatan $\mathrm{CO} 2$ dapat mengurangi kadar emisi carbon diudara. Rancangan desain biogas yang diterapkan pada mitra dapat di lihat pada Gambar 5 .
Dengan segala ukuran yang ditentukan dan bagian dengan fungsi masing-masing diharapkan menjadi desain biogas yang memiliki harga produksi rendah tapi memiliki efisensi yang tinggi.

\section{b. Tahap Pelatihan dan PendampinganTeknis}

Tahap ini bertujuan untuk memberikan edukasi tentang pemilahan sampah, jenis-jenis sampah yang dapat dimanfaatkan, hal-hal yang harus diperhatikan dalam operasionalisasi reaktor biogas seperti tekanan dan temperatur yang berguna menjaga kehidupan bakteri pengurai sampah (EM-4), serta pelatihan dan pendampingan teknis pembuatan reaktor biodigester portable kepada masyarakat dengan bahan yang mudah ditemui dan harga yang terjangkau.

\section{c. Tahapan Pengujian Reaktor Biodigester Portable}

Pengujian diawali dengan pencampurkan sampah organik pasar dengan kotoran sapi dan dimasukkan melalui inlet slurry dengan perbandingan $1: 1$ dan penambahan air setara 1 : 1, proses fermentasi dengan penambahan starter EM-4, dengan HRT(Hydraulic Retentation Time) sekitar 20-30 hari dan biogas pun siap ditampung dan disalurkan untuk dikonsumsi sebagai bahan bakar.

\section{d. Tahap monitoring danevaluasi}

Pada tahap monitoring dan evaluasi,kondisi dan efektivitas reaktor biogas, efektivitas kegiatan pelatihan pembuatan reaktor biogas, dan masalah dan kendala yang dihadapi dari masyarakat dikumpulkan untuk dicarikan solusi serta menjadi masukan bagi tim pengabdian dalam monitoring keberlanjutan program.

\section{PEMBAHASAN}

Hasil yang telah didapat dari program pengabdian masyarakat tentang program pelatihan dan pendampingan pembuatan reaktor biogas yang memanfaatkan campuran sampah organik pasar dan limbah kandang ternak adalah sebagai berikut, terdiri dari 3(tiga poin penting) pengajaran tentang cara pemilahan sampah organik dan pemanfaatannya untuk menjadi starter EM-4, 
pembuatan reaktor biogas portable sebagai studi cara kerja reaktor biogas, pembangunan dan pendampingan reaktor biogas di desa Kendal, Ngawi dan KedungBoto, Pasuruan.

Sebelum melakukan sosialisasi pada masyarakat setelah reaktor biogas terbangun, terlaksana studi internal tim tentang tata cara jenis sampah yang bisa digunakan sebagai penghasil biogas dan pembuatan starter EM-4 untuk biogas dari sampah organik berupa limbah sayur dan buah. EM4 merupakan inovasi produk ramah lingkungan yang dipergunakan sebagai produk pertanian organik sebagai sumber mikroorganisme dan aktivator. Pembuatan EM4 dengan cara fermentasi dilakukan selama 30 hari diawali dengan pencacahan bahan baku guna memperkecil ukuran, dan dilakukan fermentaasi anaerob selama 30 hari.

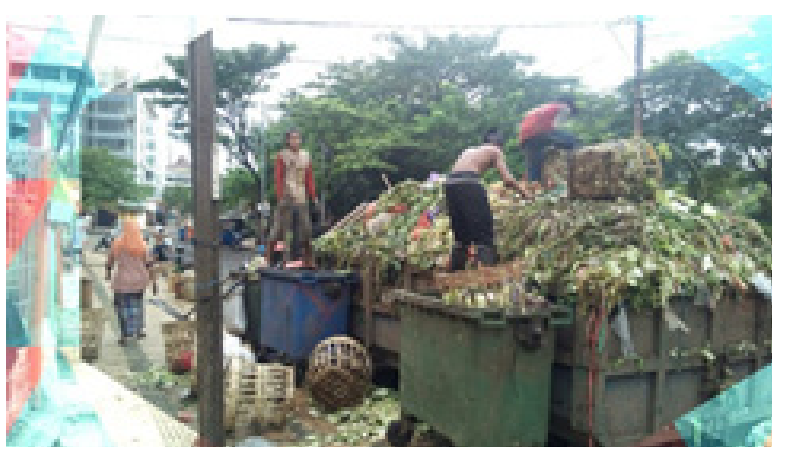

Gambar 6. Pemilahan Sampah untuk EM4 Sumber : Dokumentasi Pelaksanaan

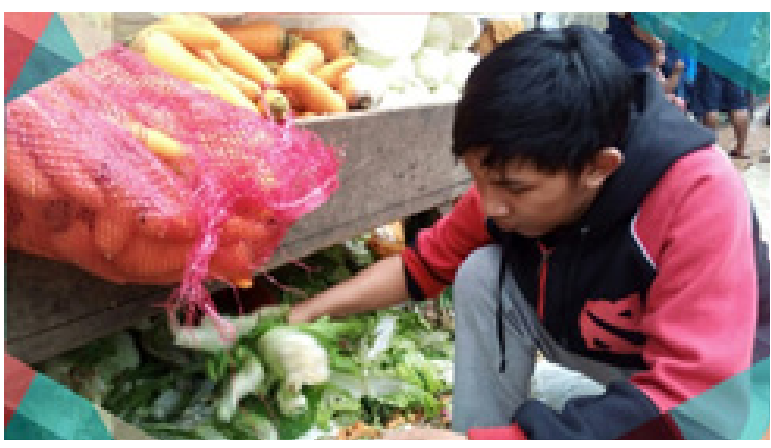

Gambar 7. Sosialisasi Limbah Organik untuk EM4 Sumber : Dokumentasi Pelaksanaan, 2018
Pada pembuatan reaktor biogas sudah terlaksanakan secara sistematis sesuai urutan pembuatan dan sesuai dengan desain yang ditetapkan terdapat digister utama, roda portable dan alat purifikasi. Permasalahan saat pembangunan reaktor biogas portable adalah tentang sulitnya memastikan reaktor ini tidak bocor atau harus kedap udara untuk proses anaerob. Saat terdapat kebocoran sambungan atau tutupan biogas tidak akan terbentuk dan adapun bila biogas terbentuk pasti langsung bergerak ke arah luar sekaligus menjadi kekurangan biogas ini disamping sedikitnya gas yang tercipta. Roda yang diharapkan menjadi portable dan keunggulan reaktor ini pada kenyataanya saat telah diisi oleh limbah sampah organik dan limbah kandang ternak ditambah air menjadikan massa biodigester tersebut menjadi sangat berat dan mengurangi bahkan menghilangkan sisi ke portableannya.

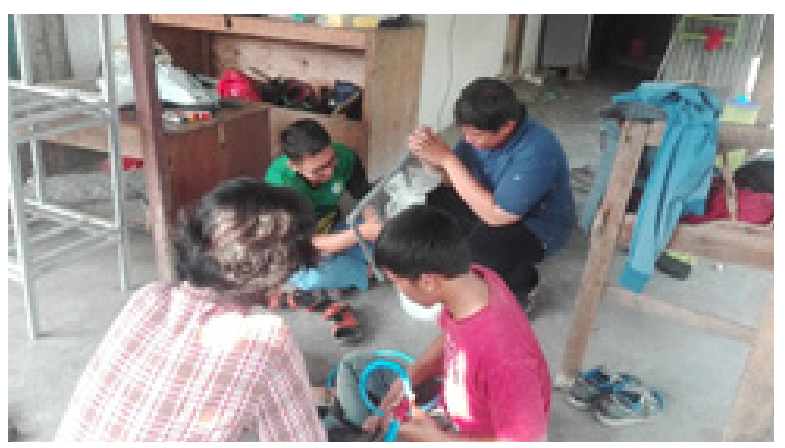

Gambar 7. Edukasi Sistem Kerja Biodigister Via Pembuatan Biodigister Portable

Sumber : Dokumentasi Pelaksanaan, 2018

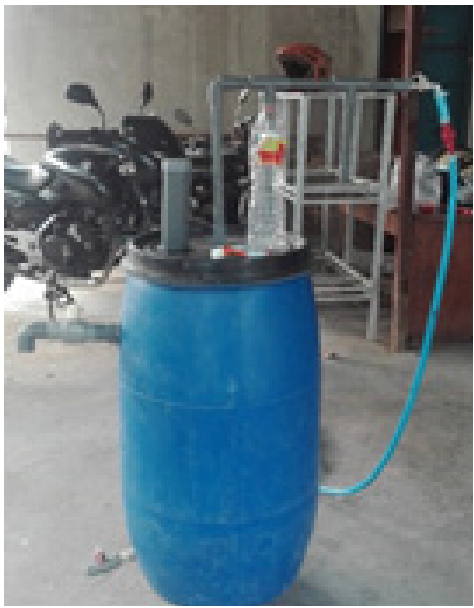

Gambar 8. Biodigister Portable

Sumber : Dokumentasi Pelaksanaan, 2018 
Sistem cara kerja biogas yang dipelajari dari biogidister portable di realisasikan menjadi biodigister berskala besar dengan desain baru yang didesain sedemikian rupa untuk bisa menghasilkan gas semaksimalnya dengan biaya pembuatan semurah-murahnya. Biodigister ini memiliki ukuran panjang sekitar lebar 0,13 $\mathrm{m}$ dan kedalaman dari permukaan tanah 2,30m.

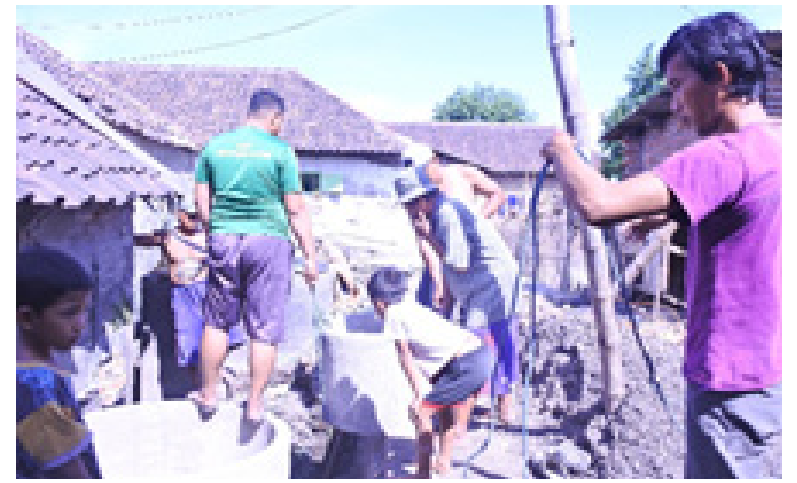

Gambar 9. Pembuatan Reaktor Biogas dengan warga desa Kedung Boto, Pasuruan

Sumber : Dokumentasi Pelaksanaan, 2018

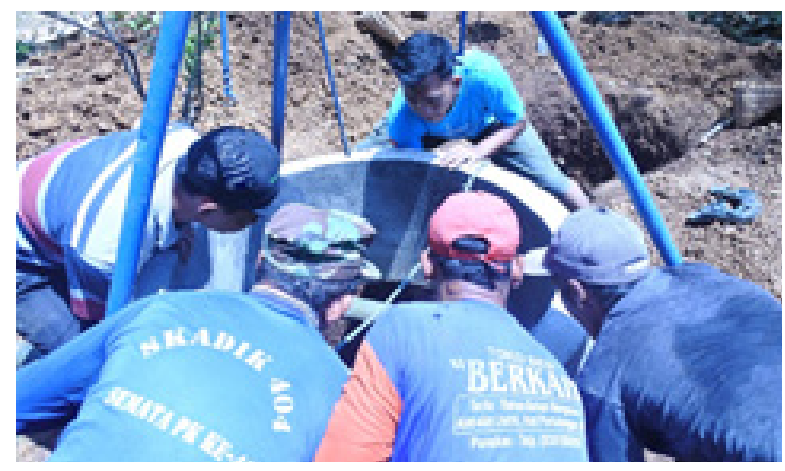

Gambar 10. Peletakkan beton buis untuk digister di desa Kendal, Ngawi

Sumber : Dokumentasi Pelaksanaan, 2018

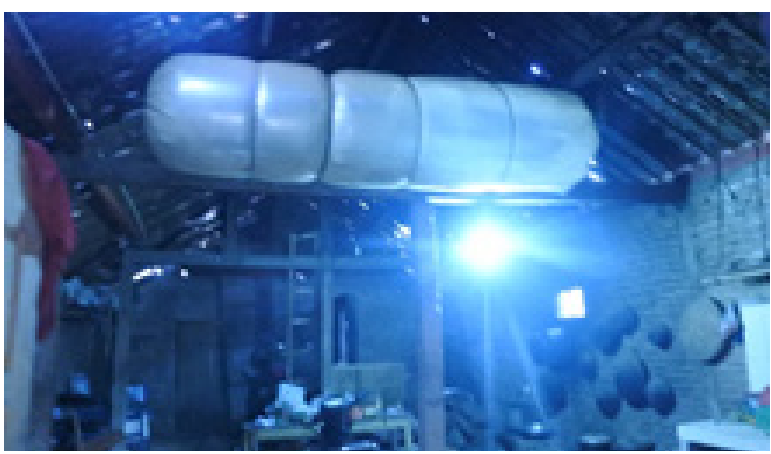

Gambar 10. Hasil Biogas Warga

Sumber : Dokumentasi Pelaksanaan, 2018
Dalam biodigister yang telah dibangun mengutamakan sisi efektivitasannya untuk merubah sampah organik dan kotoran hewan menjadi biogas. Dalam pembangunan reaktor terdapat beberapa tahap yaitu, persiapan berupa desain dan lokasi pembangunan, pembelian material, penggalian tanah, pemasangan base, pengecoran dan pemasangan antara instalasi pipa, plastik penampung menuju kompor. dapat dilihat pada Gambar 10.

Setelah berada dalam tahap pengisian limbah organik dan kandang ternak pada biodigester selama 25 hari berturut-turut dengan perbandingan bahan dan air yakni 1:1 serta penambahan EM4 dari pengolahan sampah organik warga menghasilkan data kualitatif dan kuantitatif sebagai berikut dengan harga yang terjangkau kelebihan lain dari biodigester ini adalalah tidak memerlukan lahan karena berada di bawah permukaan tanah, nyala api biru dan untuk pemakaian atau konsumsi gas oleh masyarakat biasanya masyarakat menggunakan biogas ini untuk memasang pada waktu pagi, siang dan sore hari. Untuk hasil yang bisa tertampung di plastik tampung perharinya jika dilakukan pemakaian 3 kali sehari adalah 847,8 liter.

\section{DAFTAR PUSTAKA}

[1] Badan Pengkajian dan Penerapan Teknologi. 2015. Outlook Energi Indonesia.

[2] Wahyuni, S. 2013. Biogas Energi Alternatif Pengganti BBM, Ga dan Listrik PT. Agro Media Pustaka. Jakarta Selatan. $117 \mathrm{hlm}$

[3] Hardoyo, dkk.2014.Panduan Praktis Membuat Biogas Portabel Skala Rumah Tangga \& Industri. Yogyakarta. PenerbitANDI.

[4] Nuri, M. 2017. Pengaruh Diameter Lubang Bubbles Generator Pada Peningkatan CO2, Dengan Larutan Kalium Hidroksida 4 Molar. Jember: Fakultas Teknik UNEJ.

[5] Yamtinah,Sri, dkk.2006. Studi Pustaka Pemanfaatan Proses Biokonversi Sampah Organik Sebagai Alternatif Memperoleh Biogas. Solo, UNS. 
Halaman ini sengaja dikosogkan 